
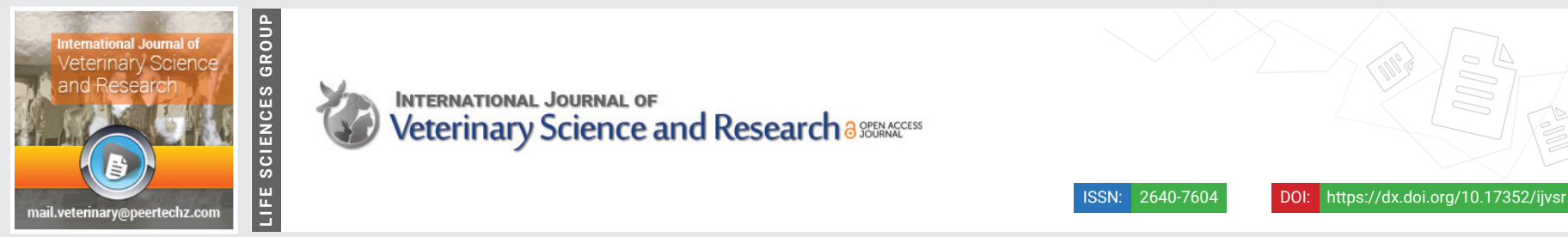

Literature Review

\title{
Review on application of hazard analysis critical control point in ethiopian slaughtering plant
}

\section{Wazir Shafi Mustefa*}

Department of Veterinary Public Health, College of Veternary Medicine, Haramaya University, Ethiopia

Received: 31 May, 2021

Accepted: 12 June, 2021

Published: 15 June, 2021

*Corresponding author: Wazir Shafi Mustefa Department of Veterinary Public Health, College of Veternary Medicine, Haramaya University, Ethiopia, Tel: +251920372943; Email: wazirshafi3@gmail.com

Keywords: HACCP; Slaughterhouse; Abattoir; Meat hygiene; Meat safety; Meat quality

https://www.peertechzpublications.com
Check for updates

\section{Abstract}

Hazard Analysis and critical Control Point system is a preventive tool for assuring the safe and sound manufacturing of foods products. It's based totally on common utility of technical and scientific standards to a meat manufacturing process. HACCP application offers with manipulate of things affecting the meat product and process. It's a hazard control mechanism wherein foods protection is addressed via the evaluation and manipulates of biological, chemical and physical dangers from within the complete meat manufacturing process. With respect to hygienic manipulate in Ethiopia, all of the prevailing export slaughterhouses have centers for shoats, however centers for livestock are restrained and there is not always hygienic manipulate within the non-export abattoir. There's little to no class of carcass best and protection, and consequently little class of economic better of Ethiopia's meat products. There is not any device of grading or naming meat. Throughout the slaughter, the animals are discovered expressing stress-associated behaviors, such consistent water and blood waft became tough and will be discovered as a hygiene problem. There's little facts approximately legal guidelines and rules regarding foods protection in Ethiopia. Therefore, from this review, it has been advocated that authorities' organs responsible for foods protection through preparing and imposing foods protection standard, legal guidelines and rules within the whole slaughtering plant. And as vocalization, head swings, and transferring forward. The environment within the slaughter corridor is demanding for livestock with excessive quantity and lots more and plenty of pastime through persons and animals within the course of slaughter, using moist and slippery flooring due to HACCP standards should additionally be implemented within the layout and implementation of hygiene measures at some stage within the whole foods chain.

\section{Abbrevations}

ABP: Animal By-Product; AGP-LMD: Agricultural Growth Program Livestock Market Development Project; AKLDP: Agriculture Knowledge Learning Documentation and Policy; APC: Aerobic Plate Count; BSE: Bovine Spongiform Encephalopathy; CAC: Codex Alimentarius Commission; CCPs: Critical Control Points; EBCQA: Export Beef Carcass Quality Audit; EPA: Environmental Protection Authority; FAO: Food and Agricultural Organization; FSIS: Food Safety Management System; FSO: Food safety objectives; GMP: Good Manufacturing Practices; GHP: Good Hygienic Practices; HCCP: Hazard Analysis Critical Control Point; ICMSF: International Commission on Microbiological Specifications for Foods; ISO: International Organization for Standardization; LLP: Livestock and livestock products; MoA Ministry of Agriculture; MoARD: Ministry of Agriculture and Rural Development; MoFEC: The Ministry of Finance and Economic Cooperation; MoH: Ministry of Health; MoI Ministry of Industry; MoT: Ministry of Trade; NACMCF: National Advisory Committee on Microbiological Criteria for Foods; NASA: National Aeronautics and Space Administration;
NCC National Codex Committee; NEPAD-CAADP: New Partnership for Africa's Development- Comprehensive Africa Agriculture Development Programme; OIE: International Office of Epizootics; QSAE: Quality and Standards Authority of Ethiopia; RMAA: Red Meat Abattoir Association; SOP Standard Operating Procedure; UNIDO: United Nations Industrial Development Organization; USA: United States of America; USAID: United States Agency for International Development; USDA: United States Department of Agriculture; WHO: World Health Organization

\section{Introduction}

Any protocol of a modern technological based foods, protection mechanism should contain a protocol of the Hazard Analysis Critical Control Point system (HACCP). HACCP is extensively identified because the desired approach for assuring protection of our foods which include meat [1].

HACCP changed into evolved within the overdue nineteen fifties and pioneered within the early sixties via way of means of the Pillsbury Company, with participation of the National 
Aeronautics and Space Administration (NASA), the Natick Laboratories of the U.S. Army and the U.S. Air Force Space Laboratory Project Group. HACCP changed into important to growing area application foods that approached as close to as feasible complete guarantee towards contamination [2]. HACCP changed into first defined in element to a huge audience at the Conference for Food Protection in 1971 [3]. It changed into then applied with tremendous achievement to low-acid canned foods in 1974 [4]. In the many years for the reason that its development, HACCP has emerge as extensively identified because the pleasant method for enhancing foods protection [2].

In modern-day international foods economic system should be related to foods security, an idea that has received a new method springing up from globalization within the foods trade, in which HACCP structures had been added to supply secure foods, in keeping with the sanitary necessities of population [5]. About $1 / 2$ of of the foods produced within the international are perishable and the motives for this lie within the bodily chemical, enzymatic and microbial-changing products. In order to inhibit or gradual down those methods in foods, engineering has evolved numerous conservation structures, appearing basically in chemical or physical methods. Among those, the chilling process is one of the widely used methods for foods preservation [6].

The short figure of HACCP is one that evokes 'foods protection'. Formerly evolved to make assure certain microbiological protection of foodstuffs, HACCP has been broadened to consist of chemical and physical risks in foods. The modern-day growing international problem approximately foods protection among public health authorities, purchasers and different concerned parties, fueled via way of means of the uninterrupted reviews of food borne 'disorder' outbreaks had been a chief impetus with-inside the creation and full-size application of the HACCP mechanism [7].

This system is designed to discover potential risks previous to they arise and to enforce manipulate movements to lower or put off the chance in their occurrence. HACCP based structures are significant because, even as meat examination and checking out is large, there's no quantity of inspection and/or checking out this is capacity of removing all risks. We have to know no longer depend solely on authority's inspection and checking out to make certain the protection of our meat. HACCP, collectively with a great inspection and checking out machine, shape the middle of any stable food's protection machine. Organoleptic inspections aren't enough. HACCP best isn't enough. Government organoleptic inspection and HACCP pass collectively every different in an as it should be technological know-how primarily based totally method to foods protection [8].

The HACCP system is a preventative arise to manage hazard during of food management and processing and is a success if efficiently implemented [9]. The application of HACCP based system with-inside the meat enterprise is presently applied in nations such as the USA [10], Australia [11] and Canada [12]. With a robust affiliation among meat intake and foods-borne disorder outbreaks, HACCP based structures had been advocated as powerful manipulate measures of risks at abattoirs. Governments across the world have regulated the compulsory implementation of HACCP based structures withinside the meat enterprise [13].

Within Ethiopia, there are actually approximately 296 municipal abattoirs and the bulk of them had been constructed over 40 years in the past through Second Livestock Development Project. Apart from a few more recent abattoirs in Adama, Jima, Hawassa and different location, maximum different abattoirs are in a country of terrible situation, and their physical, sanitary and operational situation are very poor. About $94 \%$ of those older abattoirs are positioned with-inside the internal of city or town, in which enlargement and secure waste elimination are not feasible [14]. on the opposite hand, with meat intake set to increase, the dangers of disorder, and the want to make certain accurate waste disposal, there's now an urgent need to relocate many abattoirs far from residential zones. The production of latest abattoirs is needed, in non-residential locations, and with adherence to current structural necessities, hygiene control exercise and environmental compliance [15].

Once HACCP is established, it required to be again and again evaluated, upgraded, and modified. Experience in functioning HACCP plan can be beneficial in consistent development withinside the plan. In effect, the HACCP application is a long-time period dedication to enhancing the protection of the product via way of means of controlling the process. The NACMCF has 12 steps ( 5 initial steps and the seven concepts indexed below) in growing a HACCP plan [16].

\section{Objectives}

This literature review aims to help the development of country wide policy, techniques and working plans aimed toward enhancing foods protection and exchange in the course of the application of HACCP in slaughtering plant. During this watch, bendy methods to the implementation of HACCP are defined and its major goal is to avoid wasting your foodsborne ailment. this can be likewise the vital technique of the (HACCP) gadget. The HACCP system controls or gets eliminate those risks, which can cause food borne disease and outbreaks through working out important operations and offer powerful and effective strategies for tracking and controlling them.

The purposes of this review are:

1) To review the HACCP system in relation to a meat plant.

2) To review critical control points commonly found in meat plants.

3) To review the meat safety and quality application in Ethiopia.

4) To show the gap and constraints in application of HACCP.

\section{Developing the haccp plan}

\section{The Pre-HACCP Steps}

Assemble the HACCP Team: The number one step is that the arrangement of the HACCP crew which should be trained. 
Training is usually supplied through personnel that are not HACCP practitioners who're as an alternatively lecturers, academics, regulators, or former hygiene trainers [17].

It is important to enroll within the control of foods safety risks with each the HACCP programme (within the trail of the CCPs) and manage via the preventative PRPs. HACCP skills, particularly the potential to get and examine hazard is also implemented to excellent impact whilst determine what PRP development are visiting be required. This can be frequently the most high-priced characteristic of upgrading a company's foods protection programme; as a result, it is important for you to guide the funding choices with science-based hazard estimation. Where capital funding and constructing word is very important, this may take some time; as a result, it is also essential to make your mind up how the gaps with-inside the programme is also controlled within side the brief term, i.e., while the upgrades are being assigned. The crew contributors require having an apparent information of the association of the HACCP application system, i.e., whether or not the HACCP observe methods is also linear or modular, and whether or not one product or variety product be measured. This must have already been decided during the planning phase. Linear HACCP research usually starts with uncooked substances and provides up with the finished product. Though, modular HACCP plans require to be delivered collectively to cowl the entire operation. it's vast to utterly discover the begin and provides up factors of everyone HACCP observe to confirm that every step is built-in [18].

\section{Describing the product ingredient}

The complete description of the product through giving the records and information for the ingredients, processing strategies, retail, packaging and storing circumstance should aims at identifying any risks happening to the product which the product may cause [19].

Collect records at the finished product (and probable inmethod product)

- General characteristics: denomination, composition, volume, structure.

- Physical-chemical character: $\mathrm{pH}, \mathrm{Aw}$, redox capacity (Eh), and preservatives.

- Modified atmosphere.

- Packing.

- Labeling.

- Conditions of storage and lifespan.

- Storage and distribution community situation.

* Collect records on uncooked substances

- Definitions.

- Presentation: volume, reasonably packaging.
- Formulation (\% of each uncooked cloth used).

- Physico-chemical characteristics: pH, Aw, Eh, viscosity.

- Concentration ration of the solution and components ration.

- Temperature of storages.

- Lifespan.

- Treatment, preparation, manufactured, use/principle [20].

\section{Identify the Intended Use of the entire Product}

The "supposed use" of the foods product is that the predictable use of the product through the end consumer. In some cases, it must be taken into consideration that aged, infantry and sick person are specially at risk from infected foods. For instance, pregnant ladies and unborn child are significantly at threat from Listeria monocytogenes. The deliberate use should be based at the anticipated makes of the merchandise through the last consumer or users (Jo, 2010) [21]

\section{Construct a flow diagram}

The precept of flow diagram is to supply a comprehensible, easy defined steps involved with-inside the system. The scope of the flow diagram must cowl up all the steps within the system which directly the manipulate of the establishment. Additionally, the flow diagram can include steps within the foods chain that's prior and after the processing that arise within the establishment. The flow diagram need doesn't be as difficult as engineering drawings. A block kind flow diagram is satisfactorily descriptive also, an easy schematic of the facility is often beneficial in know-how and compare product and system flow [22].

If the flow diagram is drafted through watching of work on site, the nice and maximum appropriate approach is thru vocal recording, transcribed afterwards. This allows a selected and non-stop operations statement, produced while not having to appearance away to write. [20].

\section{On-site affirmation of flow diagram}

The HACCP crew should verify the processing feature via to the flow diagram all steps and hours of operation and modify the flow diagram wherein appropriate and watch the system with a significant eye and thru the flow diagram [21] Figure 1.

The HACCP System - A Step-by-Step Approach.

\section{Principle 1- hazard analysis}

The first step in designing a HACCP plan is to carry out an evaluation of risks associated with every product. During threat or hazards evaluation the HACCP crew evaluates all the methods involved with manufacture, distribution, and using uncooked substances for potential trouble that might occur [24]. 


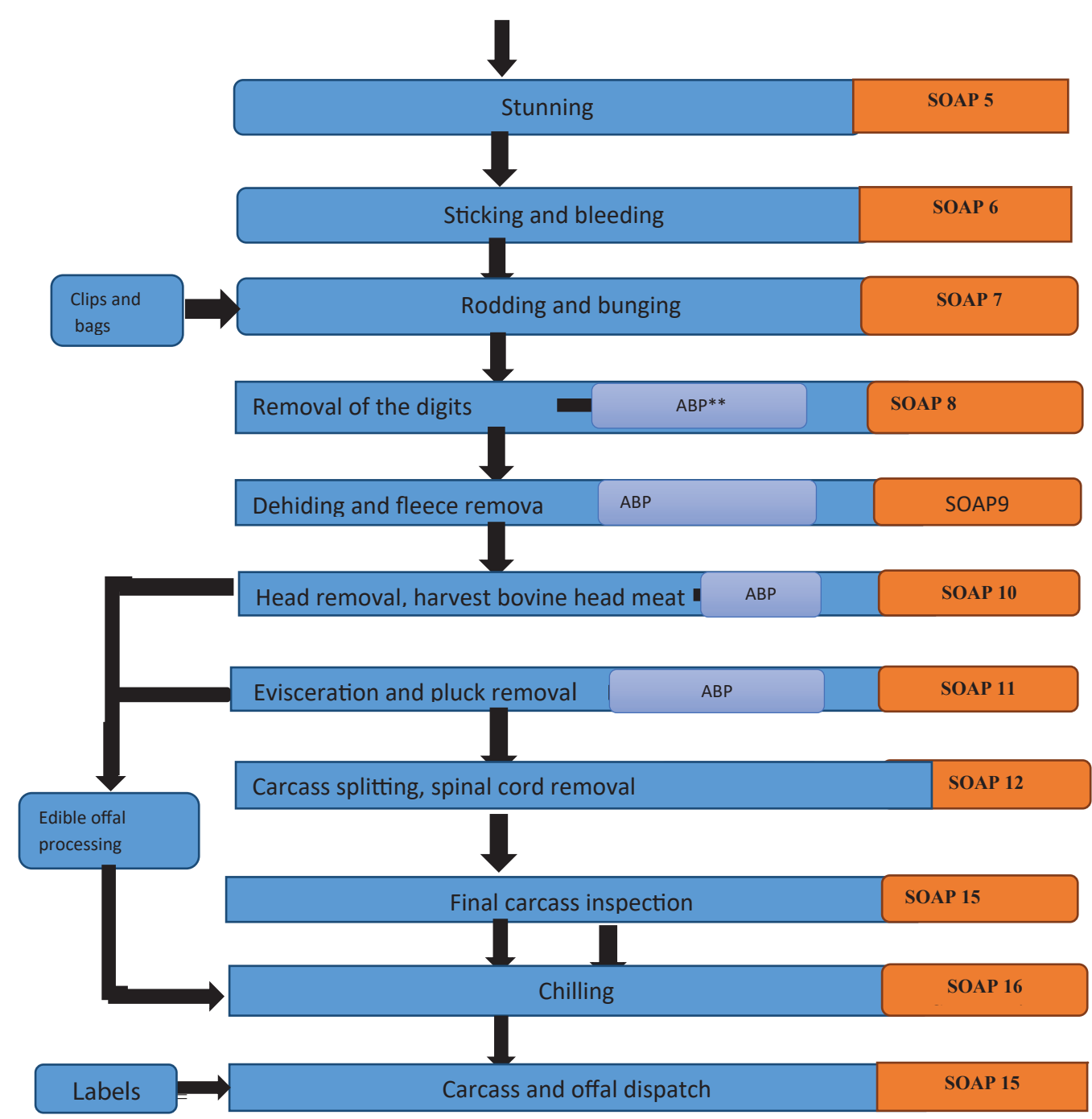

SOAP $=$ standard operating procedure

** ABP $=$ animal by-product

The HACCP crew conducts a hazards evaluation and identifies appropriate manipulating measures. Hazard evaluation is executed in stages: (a) threat identification based on a evaluation of the starting place of practicable dangers and (b) threat assessment within the body of the potential significance of every threat is classified via way of means of thinking about its cruelty (relating to health consequences) and it's like-strains to take place (primarily based totally on experience, epidemiological information and to be had records within the writing). Hazard evaluation is executed via way of means of list all signficant dangers related to each step, and all manipulating measures which could put off or manipulate those dangers to a tolerable stage [19]. If the threat evaluation isn't performed well and the danger warranting manipulate in the HACCP device aren't identfied, the plan will now no longer be powerful regardless of ways good it's followed [25].

A food safety threat is a biological, chemical, and physical agent, or scenario of foods, with the capability to causing damage or an unwanted health impact whilst the foods is eaten. Food safety dangers or hazard may be classed as [26]:

- Biological which includes microorganisms.

- Chemical which includes chemicals, pesticides, cleansing retailers and allergens.

- Physical foreign objects that aren't supposed to be within the foods, which include timber, glass, packaging cloth and certainly taking place gadgets bones, dirt, and grits.

\section{Biological hazard}

Hazards which present or live within the food and may manifest from a different source. These microorganisms (generally called "germs") are so small they could simply be visible over a microscope. Not all microorganisms are dangerous 
to humans. Pathogens are the microorganisms which can make damage to humans, even as they attain a excessive stage in foods. Some examples are [27]:

- Bacteria: Salmonella, Staphylococcus aureus, Bacillus cereus.

- Viruses: Hepatitis A, Influenza.

- Yeasts.

- Molds.

- Protozoa e.g., Giardia.

\section{Chemical hazards}

The following source had been identified.

1) Agriculture chemicals: pesticides, herbicides, animal drugs, fertilizers, etc.

2) Plant chemicals: cleaners, sanitizers, oils, lubricants, paints, pesticides, etc.

3) Naturally taking place toxicants merchandise of plants, animals or microbial metabolism which include aflatoxins, etc.

4) Food chemicals: preservatives, acids, foods additives, sulfiting retailers, processing aids, etc.

5) Environmental contaminants: lead, cadmium, mercury, arsenic, PCBs [16].

\section{Physical hazard}

A physical threat is any physical objects or materials now no longer frequently determined in a food which cause infection or harm to the people by the usage of the product. Physical dangers consist of many types of foreign substances or gadgets, which include glass, steel, and plastic. However, foreign gadgets which cannot or do now no longer cause infection or harm aren't hazards, even though they will now no longer be aesthetically desirable to the customers. A range of situations can outcome in physical dangers in completed products. They include, but are not limited to.

- Contaminated raw material.

- Inadequately designed or poorly maintained facility and device. Example might be paint chips falling from overhead systems onto uncovered product or piece of steel from worn or improperly maintained device getting into product.

- Improper methods or irrelevant worker training and practices. Example, damaged glass jars, via way of means of unsuitable loading on the road via way of means of personnel or unsuitable or insufficient situation examination, glass portions from damaged or chipped jars can be covered whilst filling product containers.
- The Sanitation SOP's may be used to apprehend and manipulate cross-contamination this is because of worker practice [28].

\section{Principle 2. Identification of critical control points (CCPs)}

A CCP is a step at which controlling may be practical and is vital to save or protect you or put off a foods safety threat or lower it to an appropriate stage. CCPs can relate to governing of widespread foods safety dangers only. Identification of CCPs may be finished via way of means of the usage of tools which include CCP decision tree. The majority extensively used decision tree are the ones published via way of means of Codex and NACMCF, but variation be presents. Raw substances can undergo the Codex pattern decision tree; however, the wording does never instances lend itself to an uncooked material scenario. Wherever agencies are introducing new raw substances on a common foundation and/or perform plenty of latest product development, it can be supportive to assess the ones dangers one after the other the usage of a greater precise uncooked material decision tree tool [29].

CCP are places in a technique, at which a few characteristics of manipulate may be carried out to govern foods safety dangers, that have been decided realistically probable to manifest. Examples of CCPs include product temperature, certification of incoming product, microbiological trying out, for foreign gadgets which include steel infection, the chemical attention of a carcass rinse or spray, and different such parameter. The step of the technique at which the critical control point is positioned does now no longer basically need to be on the factor wherein the threat is introduced. They can be located at any place deemed enough to prevent, put off, or efficiently manipulate the threat within the product produced. The control factor $r$ for a threat can be later in the technique than the factor at which the threat occurs [30].

CCPs are the ones process steps which might be critical for acquiring innocent meat, and area where the dangers have to be efficiently controlled (prevented, removed or reduced) via way of means of targeted measures. Consideration as to whether or not a given step is a CCP or now not based on the subsequent questions:

- Is the threat at this step at an unacceptable stage?

- Are manipulate measures to save you unacceptable degrees on hand at this step? (If now no longer, the step isn't a CCP.).

- If the response to each a) and b) is yes, the step is a CCP.

- However, whilst the 2 responses above are "no" and the step cannot be taken into consideration a CCP, it ought to be taken into consideration whether or not manipulate measures are on hand on the preceding step. If that is the case, a CCP ought to be assigned searching lower back to the preceding step. Even as CCP allocation can vary among abattoirs relying at the specifics of the manufacturing technique, which include the technology 
used, some everyday CCPs are not unusual place to all abattoirs [31].

\section{Principle 3. Establishing critical limits at every CCP}

A critical limit is described as a criterion that have to be met for all safety measure associated with a CCP. Every CCP could have one or extra preventive measures, which have to be nicely managed to guarantee prevention, removal or reduction of dangers to tolerable levels. All safety measure has associated with it, critical limits that offer as limitations of protection for every CCP. Critical limits can be placed for preventive measures along with temperatures, time, bodily dimensions, humidity, moisture stage, water activity, $\mathrm{pH}$, salt concentration, to be had chlorine, viscosity, preservatives, and sensory facts like texture, aroma, and visible appearance. Critical limits are probably derived from source along with regulatory standards, guidelines, literature surveys, experimental research and experts. The foods enterprise is liable for engaging competent government to validate that the critical limits will manipulate the recognized hazard [32].

There are 2 kinds of critical limits; a critical limit may be an upper restrict in which a hard and fast quantity or stage cannot be exceed. A critical limit also can be a lower restrict in which a minimal quantity is wanted to supply the secure effect. Critical limits are set for product protection and no for product quality [33].

\section{Principle- 4. Monitoring of essential limits}

Each CCP's have to be monitored to ensure that procedure continue to be in the critical limits. The HACCP crew desires to set up strategies not only for tracking every $\mathrm{CCP}$, however additionally for figuring out the frequency of CCP evaluation. Monitoring strategies have to be suitable for on-line use and have to offer an easy however fast assessment. Visual observations, aroma and measurements of temperature, $\mathrm{pH}$, moisture, and fat, etc. are normally used to reveal chicken processing CCP's. By conventional microbiological checking out strategies not been used to reveal CCP's due to the fact techniques are time consuming; however, with the appearance of recent fast strategies, microbiological checking out may want to offer treasured facts inside minutes [24].

The employee's obligation for monitoring is an essential attention for every CCP. Definite obligation will rely upon the variety of CCPs and manipulate measures and the complexity of tracking. Employees who reveal CCPs are frequently associated with production (example, line supervisors, decided online employees and protection personnel) and, as required quality manipulating personnel. Those people have to gain knowledge within the tracking approach for which they're responsible, absolutely apprehend the precept and utilization of tracking, be impartial in tracking and reporting and correctly record the final results of tracking. Additionally, personnel have to gain knowledge of in techniques, to observe whilst there's a manner in the direction of lack of manipulate. So those modifications may be made in a well-timed way to guarantee that the procedure stays beneath to manipulate ) [34].

\section{Principle - 5. Establishment of corrective action}

Corrective action at each CCP Immediately while there's an indication, that for any CCP the critical limit has been surpassed and the procedure is getting out of manipulate, a selected and pre deliberate corrective measures have to must take. Immediate outcomes the present plan of corrective action is a fast regaining of manipulate. Examples encompass leaving a infected carcass at the slaughter line and/or changing its disposition, or shifting carcasses to any other chiller if the temperature is transferring out of manipulate [31].

HACCP is a preventive technique to accurate problems before they influence the protection of the foods product human beings' consumers. Deviations from critical limits will happen, therefore, you require to have a plan to ensure the ones deviations doesn't direct to risky merchandise. Planned corrective action are the manner you do this. Thus, HACCP crew wishes to understand how crucial it's to cautiously perform this precept. For each CCP, your crew desire to plot a standardized set of measures that corporation personnel will observe whilst there's a deviation from a critical limit. These are a few questions they will ask in growing corrective actions:

- How will human beings be knowledgeable whilst the deviation occurs?

- If someone is appearing the tracking procedure, who will that man or woman contact?

- Who can be liable for controlling the product which could were tormented by the difference?

- How have to that man or woman make a choice how a good deal product desires to be managed?

- Who can be participated in finding out what to do approximately the product which could have been tormented by the deviation?

- How do we determine what became the motive of the deviation?

- Once we've got found out what became the motive of the deviation, who can be participated in finding out a way to get the procedure returned on top of things and save you recurrence of the deviation?

- If our HACCP educated person isn't on hand within the plant immediately, how are we able to get HACCP understanding to assist determine if our plan wishes to be modified?

- Who within the corporation desires to log out on any changes to our plan?

- Who can be liable for retaining the facts of everything we do in reaction to a deviation from a critical limit at this CCP? [33].

\section{Principle -6. Keeping record}

The accepted HACCP Plan and related statistics need to be 
on report on the establishment. For the bulk part, this will be the best a part of the HACCP Plan, with the intention to be audited or reviewed with the aid of using clients or regulators Sufficient record of what's and become measured and what become accomplished with merchandise that have been produced out of doors of Critical Limits are gadgets that human being's appearance to peer if the HACCP Plan is functioning. Documentation and record-retaining encompassing the complete HACCP device is complete, in the suitable format, well stuffed out and as much as to date [18].

Furthermore, the documentation may be utilized by a enterprise as proof of 'Due Diligence Defense' as required, for instance, with the aid of using the Food Safety Act 1990 (HMSO), within the Records that ought to be saved consists of all strategies and strategies associated with GMP, GHP, CCP tracking, deviations, and corrective action. Documents ought to additionally incorporate those who recorded the authentic HACCP study, instance threat identification and choice of critical limits. However, the majority of the documentation could be recorded involved with the tracking of CCPs and corrective measures that we take. Record retaining may be labored in some of ways, beginning from the handiest checklists, to record and manage charts. Manual and laptop statistics are in addition acceptable, however a documentation technique ought to be designed this is suitable for the scale and nature of the enterprise [35].

\section{Principle 7. Verification of HACCP}

Verification of HACCP is applying of procedure, strategies, assessments, and extra evaluations, moreover, to tracking to determine compliance with the HACCP plan [36]. The National Academy of Sciences (1985) mentioned that the predominant infusion of technology in a HACCP device facility on right identifications of the risks, CCPs, critical limits, and instituting right manner of verification. These strategies ought to be accomplished throughout the improvement of the HACCP plan. There is a strategy concerned in verification [32].

Validation is the early section wherein the plan is examined and reviewed. The selections organized even as running via the initial steps and HACCP concepts need to be over and over examined and proven to save you or manage recognized risks within the real world. In this stage, microbial or residual examination out may be used successfully to affirm that the technique is on top of things and is generating tolerable product. Such examination out desires clean evidence that the methods and strategies followed with the aid of using the plant for controlling risks aren't simply powerful in idea however will working on this precise plant. Continuing verification guarantees that the HACCP plan is running successfully on a everyday foundation. This kind of verification consists of such obligations as calibrating tracking instruments, checking at tracking actions and corrective action, and reviewing HACCP statistics to peer that they may be being made and saved in keeping with the plan [33].

The subsequent technique includes documented periodic re validations, impartial of audits or different verification strategies that need to be accomplished to make certain the accuracy of the HACCP plan. Re validations are accomplished with the aid of using a HACCP crew on a everyday foundation and/or every time sizeable product, technique or packaging modifications require change of the HACCP plan. The re validation consists of a documented-on site evaluation and verification of all flow diagrams and CCPs within the HACCP plan. The HACCP crew modifies the HACCP plan as necessary [32].

\section{Hygienic control in red meat abattoir}

An abattoir described as area which, registered by the controlling authority for hygienic slaughtering, examination of animals and processing meat product for human consumption [37]. The standardized abattoir needs to have certified personnel, nation of equipment, lairage, enough and transportable water deliver, excellent drainage and well-prepared sanitation device. By nature, foods from animal supply are simple to contaminate. The growing call for meat isn't always handiest quantity however additionally high-satisfactory or quality meat. The main elements that contribute for the beef high-satisfactory or quality are producers, investors, cooperatives, abattoirs, butchers, processors, and clients in Ethiopian. However, there has been much less communicative exchange inside actors. Therefore, the slaughter animals had been uncovered to special situations and exposed to different conditions while the manufacturing and transportation to abattoirs on each day basis [38].

Among the present 9 export abattoirs, the only five at the moment are serviceable. Every of the present abattoirs have facilities for sheep and goats, however facilities for livestock are insufficient in all the abattoirs and not one of the export abattoirs are currently exporting red meat. These abattoirs get their animals provided via way of means of investors or thru their agent. When the needs are extended and the supply are confined from their ordinary sources, a number of them purchase animals from massive investors at their manufacturing facility entry. When the animals arrived undergoes physical exam and is rested for 2 to a few days in a maintaining vicinity in which they acquire feed and water. Previous to slaughtering, they may be held in lairage for 12 to 24 hours with get right of entry to water however now no longer feed. During their stay of animals within the lairage, ante mortem or pre-slaughter exam need to be takes place [39].

Anti-mortem examinations of animals and autopsy or postmortem inspection of carcasses and organs had been carried out in all abattoirs seen. However, the reasons of condemnations had been often recorded within the nonpublic abattoir. The file or recording book within the public abattoirs discovered that there has been no exercise of each day recording on reasons of condemnations of live livestock. Moreover, the non-public abattoir affords quarter, semiannual and annual reviews on reasons of condemnations of live animals, carcasses and organs to local or regional bureau of agriculture. This exercise became now no longer found at public abattoirs. All abattoirs need to be capable of document and report their founding to the accountable body within 
the Ministry of Agriculture in order that the latter body will increase incorporated preventive and manipulate approach on main animal and public health crucial diseases [40].

In Ethiopia, majority of the livestock are slaughtered without stunning, not only because of spiritual reasons, however additionally due to persevered traditions and shortage of knowledge approximately on current slaughter techniques. When livestock are slaughtered without stunning a few animals may also take numerous minutes earlier than they lose mind feature and die. The delay may be aggregation of many elements, which include fake aneurysms within the severed carotid arteries and sustained blood passage to the mind [41] and former research have proven that $8 \%$ of livestock slaughtered without stunning can increase fake aneurysms within the carotid arteries (Holleben, 2007). Aspiration of blood into the higher respiration tract and lungs also can causing struggling all through slaughter without stunning [42].

Export abattoirs slaughter sheep and goats cool the complete carcass and wrap it with cotton linen at the time of delivering them. They additionally freeze offal in plastic luggage and mark them in categorized cartons for shipment. Supermarkets additionally set up shoat meat in special cuts, packing it in plastic and make the product geared up for distribution from their retail outlets. Butchers roll cuts of carcasses as in line with the order of the purchaser for put off. Hotels processing the beef into special dishes to offer on site: however, put off and the associated packing aren't not unusual place from hotels [43].

The defined HACCP device for red meat manufacturing is given via the International Commission on Microbiological Specifications for Foods [44]. In the case of red meat, for example, CCPs in abattoirs consist of chilling (CCP1) and skinning, eviscerating, and transporting (CCP2). An extra detailed, ordinary HACCP plan for red meat is defined via way of means of the National Advisory Committee on Microbiological Criteria for Foods, US Department of Agriculture [45]. However, right HACCP programme needs to be designed via every individual enterprise or abattoir for his or her very own manufacturing procedure and need to awareness on foods protection as opposed to such as different considerations, which include product high-satisfactory or quality and animal welfare, which generally tend to bring about too many CCPs [46].

In meat processing a excessive degree of certified effectiveness need to be created for the protection of the product produced via processing device, person processors and in addition to processors running below the device of manipulate. Meat processing in well known a procedure step to save you and reduce dangers to secure or safe level via making use of HACCP The preliminary step determines the varieties of dangers related to the uncooked meat which include microbiological dangers, chemical dangers and physical dangers. The main risk related to uncooked meat is microbiological and those are managed each on the farm and abattoir level. The addition of curing salt and starter lifestyle also are the critical control points. It is vital that those substances need to be of excessive high-satisfactory so one can save you the in-addition infection and need to feature effectively to provide favorable circumstance for the increase of beneficial microorganisms utilized in fermented merchandise. The fermentation degree is any other crucial CCP due to the speedy fall of the $\mathrm{pH}$ level which ends the inhibition of the increase of maximum pathogenic microorganisms. The heating and drying levels may also decrease the wide variety of organisms and inhibit their increase [47].

Meat processing technique carries the step and methods within the manufacture of processed meat merchandise Processed meat merchandise, which consist of differing types and local or regional variations, are meat of animal origin, which deliver treasured animal proteins to human diets. Thirteen animal tissues, within the first area muscle meat and fat, are the primary substances, except every so often used different tissues which include inner organs, skins and blood or substances of plant origin. All processed meat product were in a single manner or a special physical and/or chemically treated. These remedies move past the easy reducing of meat into meat cuts or meat portions with next cooking for meat dishes so one can make the beef palatable. Meat processing undergoes a large variety of physical and chemical remedy methods, usually combining a whole lot of methods. Meat processing technology consist of:

- Cutting or chopping/comminuting.

- Mixing or tumbling.

- Salting or curin.

- Utilization of spices or non-meat additives.

- Stuffing or filling into casings.

- Fermentation and drying.

- Heat remedy and smoking (Ethiopian meat and dairy enterprise improvement institute, 2017).

\section{Meat safety in ethiopia}

Meat hygiene and safety is usually much less managed in numerous growing or developing country wherein meat for human intake is normal primarily based on by inspecting visually, if at all, without normal microbiological test. A variety of research investigated the presence of pathogens alongside the entire beef deliver chain [48], while others diagnosed infection or contamination at unique level together at slaughterhouses and in retail stores in extraordinary in different locations encompass Ethiopia. Contamination and cross-transmission from raw meat is a major cause of food borne disease especially in growing or developing country [49]. According to WHO estimation, food borne sicknesses ended in six hundred million instances and 420,000 deaths resulting in close to 33 million disability-adjusted lifestyles years global with the increased mortality burden in Africa in 2010. Animal origins food example meat are principal contributor to the load. The worldwide load of food borne illness is result of the entire animal supply food and beef can be predicted at 168 and 10 disability adjusted lifestyles years per, 100,000 of populations 
respectively. But facts at the burden of food borne infection result of bad meat managing practices are imperfect [50].

Whereas meat fees can vary, the quality frequently stays low, in comparison to advanced country's requirements or standard from slaughter to re sale, there may be no formal category of carcass quality found. The export abattoirs are important to observe the entire meat previous to export in regard to a 1976 proclamation, clarified via way of set of guidelines formed by the Agricultural Ministers. Numerous of the guidelines but aren't enforced via $f$ means of abattoirs which produce meat for nearby consumers. The export abattoirs but did strictly implement the covering statement. Moreover, lots of the constructing changed into open air, in violation of component 5.1.8, at the Guidelines of Meat Hygiene. In a part of 7.1.10 the guiding rule states, pumping of air or gas inside skin and the carcass to assist skinning isn't permitted. on this approach but, changed into exactly how sheep and goat hides had been removed. These practices will result in the bacteria of E. coli 0157-H7 re-infection, the fecal dirt at the outside cover pollutes the internal meat product. Additionally, in section 2.1, of the Meat Inspection Procedures states, one of the maximum important functions of ante mortem inspection is to make certain that animals are rested sufficiently in order that signs is crucial to inspection disposition aren't masked. Most animals, still comes from the Harer region, 500km far from Addis Ababa, and slaughtered within 4 hours. The guiding rule additionally summarizes the disposal techniques for unusable carcass, bone, blood and different offal. The Agricultural minister declare that they ought to be well incinerated, and ship to a rendering plant, or as properly sanitarily disposed of. Near the Addis Ababa Abattoir but, there is a large wasteland with many scavenger birds consuming the leftovers of animals formerly discarded. Lastly, if the carcasses in an export abattoir are deemed doesn't used for export, they may be detained for a fixed amount of time, re inspected, and frequently bought to nearby customers [51].

Within Ethiopia, the beef product needs are notably increasing, and the intake of raw or under cooked meat turns into a character of status [52]. Same authors similarly stated that about $30 \%$ of the countrywide meat intake distribute is in Addis Ababa. However, the whole value chain of meat delivers from abattoirs, distribution, butchery stores to ultimate consumer aren't efficaciously dealt with to make certain the microbial quality, safety and soundness, wholesomeness and hygiene. Additionally, there may be no sufficient information concerning the assessment of foods safety practice, food borne infection, and microbial weight on meat touch surfaces of meat-processing gadget in butchery stores on a regular state. Factors should hold back authorities and different stockholders to properly observe measures at the effect of foods contamination troubles to public health. In general, microbiological contamination in foods processing plant may have a primary position in foods quality and safety [53]. Consumers may have incomplete data on safety and quality of the beef taken on usually; moreover, uncooked meat is a relatively consumable product [54].
Improving hygienically managing practices via way of means of meat handlers all through meat manufacturing, distribution, stores and sale at retail stores keep away from or lower microbial infection [55]. It may be very apparent that foods protection problem needs intervention measures within the whole meat deliver chain. To discover unique goals for intervention in special settings, an apparent information of nearby drivers to microbial meat contamination $\mathrm{s}$ alongside the meats manufacturing, processing and distributions chains is required. Within Ethiopia, there are over three hundred local slaughterhouses which deliver meat for nearby intake with extraordinary capacities and facility, but all with low primary hygienic requirements [56]. Although food borne microorganism were reported from cattle at slaughterhouses and meat within the retail, little data or information is offered regarding meat hygienic managing practices within the meat manufacturing and distribution continuum in Ethiopia [57].

Moreover, the guidelines declare that raw foods from animal ought to be kept between 1 and $4^{\circ c}$. The supermarkets observe this guiding principle strongly. Beef, sheep meat and goat meat are kept with the common temperature of one to eight degree Celsius (errors of 2.9 degrees Celsius), even as rooster is frozen at -five degrees Celsius or below. Addis Ababa butcheries are not often ready with refrigeration. $100 \%$ of the butcheries saved their meat in a room temperature, open-air surroundings display. Because simplest $8.8 \%$ of the butcheries had refrigerator for nightly storages, $91.2 \%$ of the beef kept at room temperature permanently. while supermarkets only keep their refrigerated beef a averages of two days (rooster ten days), the butcheries saved their room temperature meat for a avareges of two and a $1 / 2$ of days, with a regular most of 5 days (Ministry of Health. Food protection).

\section{Quality of meat in ethiopia}

The quality of meat is an important word and encompasses the special characteristics that define the quality of meat based on its constructive and useful qualities. Functional qualities due to the properties of productivity when there is inconsistency in the qualities that the trader intends to produce that meets the customer's specifications. Meat quality is characterized by tenderness, $\mathrm{pH}$, color, juice, flavor, and nutritional value [58]. Quality is particularly vulnerable to transportation and the manner of handling cattle includes the $\mathrm{pH}$, color, tenderness, texture, and moisture contained in cattle and the degradation of these variables are strongly identified as dark firm and dry meat, excessive $\mathrm{pH}$ and low content of glycogen [59]. Appearance quality for example, color is measured as an instrument. Rather, different aspects (juices and flavors) require a subjective approach, and the best strategy for evaluating meat quality is the ratings of educated taste panelists comparing special additions to the quality of meat consumption. Meat with a suitable sensory character is the desire of consumers, so the meat industry must consistently and generally receive meat with these characteristics [60].

A small number of butcher shops and several supermarkets reported that the beef round had the highest meat quality, but no price discrimination other than one supermarket. The butcher 
pointed out that Kitfo was rated the highest quality and there is still no price distinction. Supermarkets cut meat and pack meat in a similar fashion to supermarkets in industrialized countries. Butchers cut random pieces of meat, bones and fat and only sell per kilogram. Therefore, high quality meat is purchased in supermarkets. In the context of meat disposal hygiene, this process is also unorganized and inefficient. While supermarkets sell bones and ingredients as pet food, butchers sometimes sell bones but are more likely to throw them on the street for stray dogs. Some people are also said to dispose of bones in dustbins. However, all meat is sold. Butchers and supermarkets rely on slaughterhouses to shut down the slaughterhouses before they deliver them to their convenience. You just keep all the meat until it is sold, regardless of the time frame. Safety concerns from pathogens, chemicals, and physical hazards are not continuously monitored [61].

When the quality of meat is mentioned, it is the quality of the composition and the deliciousness of the meat. The most important parameters to consider when assessing meat quality are appearance, juice, tenderness, and taste [58]. For example, the United States and Australia use a grading system based on the age and sex of the marbling and slaughtered animal, while the South African grading systems is based on protecting external fats covering and animal age. Countries have developed a method that enables consumers to improve the consistency of products. Currently there is no grading tool in Ethiopia at all [62]. Stress on animals before and during slaughter it affects good animal welfare, but also results in undesirable results for beef quality [63]. As early as 1944, it was found that high $\mathrm{pH}$ levels of dark-cut meat were immediately linked to muscle glycogen deficiency before slaughter. Dark-cut meat is a quality fault characterized by increased $\mathrm{pH}$, excessive water conservation and muscle dark red, dry, firm, and sticky texture. This occurs when animals are treated in negative welfare situations before slaughter [64]. Most of the animals killed in Ethiopia are without stunning not only due to spiritual reasons, but also due to the lack of additional information about long-standing traditions and today's slaughter techniques. Also, when animals are slaughtered without being stunned, it can take a few minutes before some animals lose their mental function and die. Delays can be the sum of many factors, including fake aneurysms within the cutaneous carotid arteries and persistent delay may be a sum of many factors, as well as false blood vessels and continuous blood flow to the carotid arteries [41].

Quality management method. In addition, to measure the quality of meat available on the market, it is important to have a complete code or to list meat requirements nationwide. Establishment of quality requirements for consumer protection and the shelf life of meat used in the manufacture of quality meat and meat products and their evaluation. In Ethiopia this common form is not fully advanced. The first and most important step of this kind is to have data on the quality parameters of specialty meat, which are not present in Ethiopia [65].

\section{Beef carcass quality audit establishing in Ethiopia}

Carcasses quality auditing is a way to explore and test the degree of carcass problems. It is a foundation for developing an educational plan to deal with identified problems. Quality problems can be solved, which is usually identified by the efforts of the rangers. Criteria first rate parameters are established to achieve the development of a particular $\mathrm{C}$ language or region over the years. A method has been developed to reduce the frequency of mistakes. In addition to Ethiopia's ambitions to increase Ethiopian ambitions, audits are being made to increase the first rate of pork. Quality issues in pork carcasses are evaluated and educational packages are designed to address those challenges. The carcass class method, developed in 2012 with the help of using the Ethiopian Standards Agency, offers a first-class possibility to conduct a Beef Carcass Quality Audit (EBCQA) at an export slaughterhouse in Ethiopia. The foundation for the implementation of an export slaughterhouse application is that of higher centers and first-class practices for recording in slaughterhouses than nearby slaughterhouses [66].

\section{Observed hygiene problem in slaughtering plant}

The World Organization of Animal Health, the veterinary provider of the exporting country has essential duty for the certification of slaughtered animals [67]. But that is still a severe trouble in Ethiopia. Mainly, animals have been brought to the lairage, from extraordinary and numerous markets to the middle of Addis Ababa (Kera abattoir) in which there has been no cover, which in turn maintains them from the daylight or heavy rainfall and in which feeding and watering provision relay at the want of costumer without permission of veterinarian. During slaughtering, the animals have been confirmed expressing pressure related behaviors, e.g., vocalization, head swing and the animals pass forward. The scenario in the slaughtering plant has stress for cattle with increased sound and few movements via way of means of people and animals at some stage in slaughtering [68].

The interior surroundings situation of the slaughter corridor or hall changed into worrying for the animal with excessive extent and masses of activity via way of means of people and animals. The number one trouble to look at some stage in the slaughter manner changed into the moist and slippery ground because of a normal water and blood flow. While the animals resisted moving, they simply slipped at the moist ground and all the butchers and animals have been exposed to excessive opportunity to injuries. The normal water flow can also be tested as a sanitation difficulty and masses of bacteria can contaminate the water in Ethiopia [69]. and shall now no longer be get in contact with the carcass. To make use of water at some stage in slaughter also can be a health risks, considering that moist slaughter has been exposed to have a better risk of letting bacteria's developing within the moist surroundings at the carcass [70]. To manipulate this, the slaughter needs to be takes place in a dry surroundings or environment, that doesn't favorable for the bacteria's development [69]. In this section, it's also important to similarly look at the time of slaughter; how lengthy does it take timing among killing and transport of meat? The time of slaughter is important in some factor and may be an essential function for the beef quality. An extra hygiene and health trouble is the step in which the carcass is separated into two, via way of means of the usage of an axe and 
reduce in a directly line at the bone marrow. As nearly without delay the bone marrow is touched, the chance of spreading in all likelihood Bovine Spongiform Encephalopathy, BSE, is extraordinarily excessive [70].

In the whole municipal abattoirs, bleeding action was worked at the ground and at the horizontal posture. Even if horizontal bleeding maximizes quicker bleeding action, and it isn't always hygienic than vertical bleeding [71]. Furthermore, within the public abattoir's evisceration may be made at the soiled ground without a flying the skin. This can lead to show carcasses for infection via way of means of blood and dust and dirties from the skin. This might more greatly contaminate the carcasses and have an effect on the quality of meat. This can be the result for bad quality of red meat pronounced within the nearby or local markets of Ethiopia [68].

Despite the growing quantity of municipal slaughterhouses, casual semi-processing/home-processing each from commercial businesses (e.g., hotels, eating places, etc.) and at family stage is usual exercise in Central-Eastern Oromia. Hotels and eating places slaughter animals (frequently shoats) of their outdoor for their delivery and serve the beef to their consumers. They purchase animals from smallholder and specialized producers directly (normally via informal channels) on normal foundation however while not having binding agreement with their suppliers [72]

From the general public abattoirs, the employee transported carcasses from conveyer bar to the automobile on their shoulder. They wore plastic robes which enclosed their head and their backside. however, the hygienic scenario of those clothing changed into now no longer as much as the same old essential for abattoir employees. Workers on the abattoirs did now no longer put on hygienic aprons, clothes, boots, mesh gloves and hair caps during meat processing. This situation may be the purpose for excessive aerobic plate count (APC) in red meat promote at limited markets in Ethiopia (Kumar et al, 2010) For maximum hygienic activities and manufacturing of excessive quality meat, employees on the abattoir need to make certain their hands are continuously clean, and additionally put on uncontaminated or clean protecting garb to cowl each in their frame and hair. Throughout transporting of carcasses to butchery, quartered carcasses have been hanged within the car from touching the ground of the car. The rumen, intestines and head have been placed on the ground underneath placing carcasses. This situation similarly promotes the opportunity of microbial infection because of the get in contact among carcasses and organs [66].

\section{Standard and regulation in controlling food safety in ethiopia}

Regulation of food safety in Ethiopia: Food law in Ethiopia can be not usual obligation of Ministry of Health, Ministry of Agriculture and Rural Development, Ministry of Trade and Industry, and Quality and Standards Authority of Ethiopia. However, there's no robust coordination and cooperation among those authorities' regulatory agencies. There's additionally no complete foods regulation that in short defines and streamlines the activities of each regulatory body [73] Furthermore, the winning legal guidelines and standard exist presently are old and could now no longer solution for modern foods quality and query of safety. Hence for the purpose of figuring out the difficulty and demanding situations associated with foods great law in Ethiopia, worldwide foods requirements pointers and decided on nations enjoy characteristic beneficial instruments. Within the past decade, massive efforts are made at the country wide degree in the direction of improvement and implementation of food law control structures to guarantee food law inside the agri-foods chain. This is regularly confirmed via way of means of a couple of Codex Alimentarius guidelines and National Codex Committee (NCC) [74].

The Federal Democratic Republic of Ethiopia issued its initial proclamation on public health in 1947 that contained the surveillance of food nutrients and drinks and additionally the sanitation of constructing and facilities. Lately 2 new proclamations on Trade Practice and Consumers' Protection proclamation 685/2010 and Commercial Registration and Business license proclamation 686/2010 have been introduced with the purpose to make contributions in the direction of attaining higher leads to foods safety assurance (FAO, 2008).

The public health proclamation of Ethiopia, No. 26/1947 gives, in its preamble, that the proclamation is enacted for the safety of the health of the humans and consequently the sanitation of the towns in Ethiopia. Legal observe No. 25/1943, that is issued below proclamation No. 26/1942, additionally holds the goal of shielding public health via way of means of empowering a medical officer of health to want the attack of any food stuffs when, in the officer's opinion, such foods are discovered to be risky to public health if consumed. Shortly stated, the law prohibits the intake of foods which have the chance of affecting the health of the overall public [75].

National Codex Committee sets Ethiopian standards by energetic participation of all shareholders which might be supposed to require component to make certain its powerful implementation. In maximum cases, the involvement in the guidance of the Ethiopian standard is effected in 2 spheres/ layers: via taking part in attending the assembly of technical committee, and via commenting at the draft standard which might be made to be to be had for public. Ethiopian standards are organized by technical committees crafted from professionals from authorities, industry, use organizations and different sectors of the economy (Mulat Abegaz, 2004).

However, in Ethiopia the feeding system is extraordinarily little advanced and isn't prepared to aid the assembly, deliver and distribution of safe foods to the place community and to the export market. It's additionally not able to shield in large part the overall public from viable re assets of food borne sicknesses that might arise even to a failure to apply the famous standards of foods protection which might be hooked up over some years, as an example, fundamental hygiene practices. This has been resulted in the proliferation and in in recent times food borne sicknesses would possibly serious health issues in the country [76]. 
The legal notice No. 147/1950, that is issued with regards to foods, gives those greens vegetables irrigated or irrigation of vegetable with water containing human excrement will be taken into consideration as risky to public health and risky for intake. Meat for available now no longer bearing the stamp or approval of the overall public municipal or of the slaughter residence will be taken into consideration risky for human intake; milk from animals having Tuberculosis, infectious abortion or suppurating wounds will be taken into consideration risky for human intake. Public health proclamation No. 200/2000 has additionally goal of increasing the health of the society and developing health environments for the long-time generation thereby permitting it assumes its obligation. standard we can say that law given connection with shielding the safety and great of foods and foodstuffs has inherit pressure with the goal of safeguarding the health of the overall public from health dangers bobbing up from intake of foods and foods products [77].

\section{General principle of meat hygiene}

Meat ought to be secure and appropriate for human intake and all fascinated events along with government, enterprise and customers have a position in accomplishing this outcome.

The authority needs to have the legal strength to set and implement regulatory meat hygiene necessities and have duty for verifying that regulatory meat hygiene necessities are met. It is the duty of the establishment operator to supply meat this is secure and appropriate according with regulatory meat hygiene necessities. There have to be legal responsibility on applicable events to offer any records and help as can be required with the aid of using the competent authority.

Meat hygiene programmes need to have as their number one intention the safety of public health and need to be primarily based totally on a systematic assessment of meatborne dangers to human health and do not forget all applicable foods protection dangers, as diagnosed with the aid of using research, tracking and different applicable activities.

The ideas of foods protection risk evaluation need to be included anyplace viable and suitable within the layout and implementation of meat hygiene programmes.

Wherever viable and practical, in a competent government need to formulate food safety objectives s (FSOs) in keeping with a risk based on method with a view to objectively specific the extent of hazards manipulates this is required to fulfill public health goals.

Meat hygiene necessities need to manipulate hazard to the finest volume attainable all through the complete foods chain. Information had taken from manufacturing need to be taken under consideration with a view to tailor meat hygiene necessities to the spectrum and occurrence of dangers within the animal populace from which the beef is sourced.

The establishment operator needs to practice HACCP principles. To the finest volume attainable, the HACCP ideas need to additionally be carried out within the layout and implementation of hygiene measures all through the complete foods chain.

The competent authority needs to outline the position of these employees concerned in meat hygiene action wherein suitable, along with the particular position of the veterinary inspector.

The variety of activities concerned in meat hygiene need to be completed with the aid of using employees with the ideal training, knowledge, abilities and potential and wherein described with the aid of using competent authority.

The competent authority needs to affirm that the establishment operator has good enough structures in vicinity to hint and withdraw meat from the foods chain. Communication with customers and different fascinated events need to be taken into consideration and undertaken wherein suitable.

As suitable to the circumstances, the effects of tracking and surveillance of animal and human populations need to be taken into consideration with next overview and/or change of meat hygiene necessities on every occasion necessary.

Competent government need to understand the equivalence of opportunity hygiene measures wherein suitable and promulgate meat hygiene measures that obtain required effects in phrases of protection and suitability and facilitate truthful practices within the buying and selling of meat [31].

\section{Proclamations, regulations, and guidelines}

Proclamations: To start with, concerning the law of the high-satisfactory and protection of meat and meat merchandise, there may be meat inspection proclamation No. 274/1970, and its modification proclamation No. 81/1976. This proclamation offers with the management and inspection of meat and meat product and is likewise involved with institutions handling the identical. There is likewise proclamation wide variety $267 / 2002$ which is likewise supposed to cope with the prevention and management of animal disease to protect the high-satisfactory and safety of animals and animal merchandise. Under proclamation No, 274/1970, and its modification proclamation No. 81/1976, the animal health officer is empowered to work inspection on meat and meat merchandise to figuring out whether or not they meet the standards set through government; and, on the identical time, it prohibits the sale or disposal of meat and meat merchandise. This is to make sure that domestically produced meat and meat merchandise are secure and of correct high-satisfactory and suit for human consumption [78]

Regulations: Meat inspection No 428/1972. Sets rules for abattoirs and business institutions handling slaughtering, preparing, and processing of LLP for export from or import into Ethiopia.

(Draft) Animal disease prevention and management law. Aims at improving the disorder reporting, research, and surveillance mechanisms at federal and nearby levels. It additionally sets modes of operation for intervention and management of disease outbreaks. 
(Draft) Regulation to manipulate motion of animal and transportation of animal merchandise \& by products. Sets mechanisms to protect spreads of infectious disease out of the foci of prevalence and growth self-belief of recipient/uploading countries.

(Draft) Regulations to offer for the registration and licensing of animal health professionals. Issues rules governing the registration of animal health professionals, shipping of offerings and different miscellaneous provisions [79].

\section{Guidelines}

Meat inspection, hygiene and building of export abattoir, 2000. Adopt requirements for correct exercise to make sure bio-protection measures and reinforcement mechanisms.

Operational approaches of export abattoir. Routine approaches relating information of examining of animals destined for slaughter, choices on ill-health findings, sanitary precautions and measures in abattoir environments (NEPADCAADP, 2005) [80].

\section{Role of government agencies}

Government organs have a strategic part within the implementation of HACCP similarly to an operative function in organizing the powerful and ongoing evaluation of HACCP structures of the food's enterprise. Government organization must offer the essential infrastructure which is conducive to the implementation of HACCP structures with the beneficial useful resource of using enterprise, which embody training, education, evaluation of compliance, enterprise guidelines, and coordination among governmental corporations and specific establishments on the identical time as managing enterprise. With regard to the real evaluation of HACCP, authorities' corporations furthermore play a critical function in imparting guidance at the evaluation method had to be evolved and furnished to officers for its uniform and proper application. This guidance must be evolved with the beneficial useful resource of using authorities' corporations in collaboration with, on the identical time as possible, foods manipulate officers and enterprise [81].

The most critical authorities' organs accountable for foods protection in Ethiopia are the Ministry of Health (MoH), Ministry of Agriculture and Rural Development (MoARD) and the Quality and Standardization Authority of Ethiopia (QSAE). The MOARD is empowered with the beneficial useful resource of using Proclamation No.274 of 1970 and the amended Meat Inspection Proclamation No.81/1976 to perform meat inspection in export and nearby abattoirs. Regulation No.428 of 1972 has been promulgated to implement the above proclamation. The Regulation describes $\mathrm{t}$ the facility and accommodations needed to adopt ante-mortem inspection, techniques of post-mortem inspection, and lists judgments on some of illnesses identified at the time of ante-mortem and autopsy inspection. The Federal Ministry of Health has amended the Public Health Proclamation No.200/2000 and has currently enacted Proclamation No. 661/2009, which lets in to control the protection and awesome of foods. The new act entitles the
Ministry to set foods requirements, problem licenses to transcountry by foods corporations, manipulate the import, export, distribution, storage of foods and manipulate the awesome of foods laboratories. According to the new proclamation, the Ministry can issue, renew, hunch and revoke licenses for foods processing plants, foods importers, and exporters. The Ministry can provoke legislation and policies to enhance foods protection, adopt positioned up marketplace surveys to make sure foods protection, dispose expired foods and manipulate unlawful trade [82].

For a number of reasons, the NACMCF did not genuinely cope with the proper problem of whether HACCP must be voluntary or mandatory. This problem, however, can be approached through the same sense utilized by Codex, and others, for identifying whether microbiological necessities must be set up for a food. Codex states that, 'the motive of microbiological necessities for foods is to defend the health of the customer with the beneficial useful resource of using imparting safe, sound and healthful merchandise and to fulfill the necessities of honest practices in trade' [83]. Regulatory corporations are chargeable for verifying that enterprise is generating safe meat and chicken merchandise. To satisfy their obligations of verification, regulatory corporations that are chargeable for meat or chicken inspection need to have get entry to the ones facts which pertain to the HACCP plan. This have to encompass, for example, the HACCP plan and facts which pertain to CCPs, deviations, corrective actions, revalidations and the education and training of individuals that are worried in enforcing the HACCP plan [83].

The Quality and Standard Authority of Ethiopia (QSAE) is likewise empowered with the beneficial useful resource of using proclamation $102 / 1998$ to set foods requirements. The QSAE has evolved various requirements associated with quality guarantee and the protection of foods of animal origin, that are speculated to be accompanied with the beneficial useful resource of using all stakeholders - enforcing government and compilers like manufacturers, marketplace agents, industries. Thus, there are few acts with big scope to cope with foods protection issues through the real sort of implementing corporations is doubtful from the acts as every ministry can also additionally furthermore have numerous corporations at the floor with frequently overlapping mandates to implement the provisions within the legislation. There is also overlaps some of the mandates of $\mathrm{MOH}$ and QSAE. There is little near cooperation and co-ordination some of the 3 employer which has ended in duplication of works, wastage of the meagre human and monetary resources. An unsuccessful try has emerge as made to set up a Technical Committee to coordinate and liaison the foods protection activities performed with the beneficial useful resource of using different ministries and corporations, after which a National Food Safety Council have emerge, with participants drawn from the private and non-private sectors. Its roles and obligations encompass the following:

- Establish and coordinate the powerful foods protection guarantee device. 
- Formulate powerful foods protection coverage and method and look at for their approval and implementation.

- Establish and make stronger foods safety data record, education, communication, training among regulatory bodies, inspection government, establishments, manufacturers, and consumers.

- Strengthen the foods safety inspection, tracking and epidemiological studies.

- Establish foods standards and updates foods protection regulation and set up food's protection fund.

- Harmonize the national foods protection device with global necessities.

- Establish institutional preparations for powerful foods protection management

- Establish and make stronger risk evaluation capability and studies in foods protection [82].

In addition, Government has a function in biosafety by implementing a strategic and merged method to analyzing and handling those risks. While bio-safety competencies are essential to defend agriculture, the foods enterprise and the environment, similarly they play a critical role in protecting human health and customer self-assurance in foods [84-89].

Country like South Africa has evolved legislation governing abattoir operations which includes The Meat Act, 2000, and the Animal Protection Act, 1962 and 1935 for Animal Welfare Maintenance [71]. This form of legislation must be evolved for public and personal abattoirs in Ethiopia to make sure public health protection, welfare of animals, maximize general overall performance and awesome of meat. Hazard analysis critical control points, device is strongly advocated in all abattoirs. By often reporting measurements of critical control points, numerous critical operations which may be performed with the beneficial useful resource of using workers, handling, and slaughtering of animals may be monitored to make sure that they'll be performed properly, main to regular enhancements in welfare and operational awesome. Monitoring and assessment of the CCPs must be performed on a everyday basis [31].

\section{Conclusions and recommendations}

Hygienic manufacturing of meat isn't only essential with admire to the safety and quality of the meat, however additionally for animal welfare. Different microorganisms have special origins and, hence, require special manipulating measures. The use of foods safety and quality guarantee in slaughtering plant could be very to lessen physical, chemical, and microbiological dangers in meat products. A regulatory standards implementation in slaughtering plant and longtime planning is needed to achieve meat protection.

HACCP is an advanced system in comparison to the conventional sampling and testing of quality manipulation. Not only because it is a prevention instead of a reaction which lessen the risk of processing and selling unsafe products, but also because it is a cost-effective system which is fairly helpful in meat and meat products production.

Operational pre-considered schedule and hazard evaluation want to be mounted for the powerful applicability of HACCP that decide physical, chemical, and microbiological dangers in meat industry.

The promotion of using of HACCP through government companies for foods-borne disease control is particularly subjective. Perception of control dedication and its significance through the group of workers alongside its capacity effect at the HACCP technique calls for in additional study. There aren't any agreed equipment and strategies for the size of HACCP effectiveness and the elements impacting HACCP success across the world.

In Ethiopia besides export abattoir most meat plant isn't performing a many of the activities required for a HACCP system. Therefore, based totally upon the above conclusions the subsequent recommendations are forwarded:

Workers participated in slaughtering plant from point of slaughtering until selling of meat need to be properly educated within the monitoring approach of HACCP principles.

HACCP systems need to be promoted by government companies as a preventive tool for foods-borne disease controlling.

Internationally agreed tools and strategies for the measurement of HACCP effectiveness need to be developed.

\section{References}

1. Pierson M (2004) An Overview of Hazard Analysis Critical Control Points (HACCP) and Its Application to Animal Production Food Safety, Conference of Research Workers in Animal Diseases. USDA.

2. Fortin ND (2003) The Hang-Up with HACCP: The Resistance to Translating Science into Food Safety Law. Food and Drug Law Journal 58: 565-595. Link: Link: https://bit.ly/35fCLKv

3. Archer DL (1999) The Need for Flexibility in HACCP. Food tech 44: 174. Link: https://bit.ly/35eUsKd

4. Riswadkar AV (2001) An Introduction to HACCP: The Hazard Analysis and Critical Control Point System for Food Processors, professional safety 33-36.

5. Likar K, Jevsnik M (2006) Maintaining Cold chain in food trade. Food Control 108-113.

6. Degefa Y (2014) Evaluation of chilled goat carcass quality along the cold chain loaded from two export abattoirs in Ethiopia'. Bishoftu, Ethiopia. Link: https://bit.ly/3guCisY

7. Rushing JE, Ward DR (1999) HACCP Principles. Food Safety FSE 99-21, N.C State University Cooperative. Link: https://bit.ly/3cBwaxN

8. Haines RJ (2004) review into the meat regulatory and inspection regimes in ontario. The meat inspection review. Ministry of the Attorney General. Toronto, Ontario.

9. Brashears MM, Burson DD, Dormedy ES, Vavak L, Mcke SR, et al. (2001) HACCP implementation and validation in small and very small meat and poultry processing plants in Nebraska. Dairy, Food and Environmental Sanitation 21 20-28. Link: https://bit.ly/3gp74TW 
10. Teratanavat R, Hooker $\mathrm{NH}$ (2004) Understanding the characteristics of US meat and poultry recall: 1994-2002. Food Control 15: 359-367. Link: https://bit.ly/3wmgruF

11. Horchner PM, Brett D, Gromley B, Jenson I, Pointon AM (2006) HACCP based approach to the derivation of an on-farm food safety programme for the Australian meat industry. Food Control 17: 497-510. Link: https://bit.ly/3cDZPGR

12. Jayasinghe-Mudalige U, Henson S (2007) Identifying economic incentives for Canadian red meat and poultry processing enterprises to adopt enhanced food safety controls. Food Control 18: 1363-1371. Link: https://bit.ly/3zrCgKW

13. Govender R (2016) A review of HACCP and the South African abattoir hygiene management system towards integration. Int J Food Safety Nutrition and Public Health 6: 65-84. Link: https://bit.ly/3pRydTO

14. AGP-LMD (2016) Standardization of Domestic Abattoirs in Ethiopia. CNFA Consultancy Report. Addis Ababa, Ethiopia

15. AKLDP (2017) Meat Safety Matters. USAID/Ethiopia - AKLDP Project, Addis Ababa Ethiopia. Link: https://bit.ly/3iDLmhT

16. USDA FSIS (1996) Generic HACCP model for beef slaughter. Internationa Meat and Poultry HACCP Alliance. USDA, Food Safety and Inspection Service. Kansas City, Missouri. Link: https://bit.ly/2TZNpT7

17. Mortimore S (2001) How to make HACCP really work in practice. Food Control 12: 209-215. Link: https://bit.ly/3gvuA1Q

18. Mortimore SE, Wallace CA (2015) HACCP: A food industry briefing, $2^{\text {nd }}$ Edition Published by John Wiley \& Sons, Ltd. Link: https://bit.ly/3gjeR6Y

19. Arvanitoyannis IS, Hadjicostas E (2001) Quality Assurance \& Safety Guide for the Food and Drinks Industry. Part II Quality Assurance and ISO 9000: 2000 and Part IV Food Safety Hazard Analysis Critical Control Point (HACCP), Arvanitoyannis, I.S. (ed), Chania:Mediterranean Agronomic Institute 73-83.

20. Bonne R, Wright N, Camberou L, Boccas F (2005) Guidelines on HACCP, GMP and GHP for ASEAN Food SMEs,A comprehensive hand-book to assess your hygiene practices and HACCP system. EC-ASEAN Economic Cooperation Programme on Standards, Quality \& Conformity Assessment (Asia/2003/069236). Link: https://bit.ly/3wip1dl

21. Jo KB (2010) Review of food safety assurance and application of HACCP in production of sea frozen squid in DPR of Korea. United Nations University Fisheries Training Programme, Iceland. Link: https://bit.ly/35hqWU3

22. NACMCF (1997) Hazard Analysis and Critical Control Point principles and application guidelines.

23. Food Safety Authority of Ireland (2019) Food Safety Management System (FSMS) Guide for Low-Throughput Cattle, Sheep, Goat and Pig Slaughterhouses, Section E: Hazard analysis and critical control point. Dublin Ireland.

24. Northcutt JK, Russell SM (2010) General Guidelines for Implementation of HACCP in a Poultry Processing Plant. Link: https://bit.ly/3wmf3rH

25. Corlett DA (1998) HACCP User's Manual, Gaithersburg, MD: Aspen Publishers 93: 121. Link: https://bit.ly/3xI6v4E

26. Rejendran M (2010) Concepts of food safety and quality management systems. FSSAI. regulators training.

27. NSW HSC (2014) Food safety hazards.

28. USDA (1997) Guidebook for The Preparation of HACCP Plans. United States Department of Agriculture. Food Safety and Inspection Service, Washington, DC. Link: https://bit.ly/3iBQ3IX

29. ILSI (2004) A Simple Guide to Understanding and Applying the Hazard Analysis Critical Control Point Concept, 3rd edn, International Life Sciences Institute Europe, Monograph Series, ILSI Europe, Brussels, Belgium.
30. NACMCF (1998) Hazard Analysis and Critical Control Point Principles and Application Guidelines, The National Advisory Committee on Microbiological Criteria for Food (NACMCF). Journal of Food Protection 61: 1246-1259. Link: https://bit.ly/3p06VxU

31. FAO/WHO (2004) Draft Code of Hygienic Practice for Meat. Report of the Tenth Session of the Codex Committee on Meat Hygiene. ALINORM 04/27/16 Rome.

32. NACMCF (1989) Hazard Analysis and Critical Control Point system.

33. USDA (1999) Guidebook for the Preparation of HACCP Plans, Washington: USDA. Link: https://bit.ly/3xn0Gn0

34. Sneed J, Strohbehn C, Gilmore S (2004) Food safety practices and readiness to implement HACCP programs in assisted-living facilities in lowa. Journal of the American Dietetic Association 104: 1678-1680. Link: https://bit.ly/3guodvz

35. FAO/WHO (2001) Codex Alimentarius - Food Hygiene - Basic Texts, 2nd edn, Rome, Italy.

36. FAO/WHO (2001) Manual on the application of the HACCP system in mycotoxin prevention and control. Rome. Link: https://bit.ly/3pQ0JoV

37. Akpabio U, Kalu E, Babalola SA (2015) Assessment of Facilities and Slaughte Practices in Aba Abattoir, Abia State, Nigeria. Journal of veterinary advance 5 957-961. Link: https://bit.ly/3wogZ2W

38. Alemayehu K (2011) Value chain assessment of beef cattle production and marketing in Ethiopia: challenges and opportunities of linking smallholde farmers to the markets. Livestock research for rural development. Link: https://bit.ly/3vliy0u

39. USAID (2013) Value Chain Analysis for Ethiopia: Meat and Live Animals; Hides, Skins and Leather; and Dairy. Agricultural Growth Program - Livestock Market Development (AGP-LMD) project. United States Agency for International Development (USAID). Link: https://bit.ly/3iRXBaX

40. Mummed YY, Webb EC (2015) Operation, facilities and management in public and private abattoirs in Ethiopia. Afr J Agric Res 10: 623-630. Link: https://bit.ly/3pSjvfj

41. Blackmore DK (1984) Differences in behaviour between sheep and cattle during slaughter. Research in Veterinary Science 37: 223-226. Link: https://bit.ly/3vgQfA1

42. Gregory N, Fielding H, von Wenzlawowicz M, von Holleben K (2010) Time to collapse following slaughter without stunning in cattle. Meat Sci 85: 66-69. Link: https://bit.ly/3ghNV7Q

43. Ethiopian meat and dairy industry development institute (2017) Feasibility study for the establishment of meat products processing. Bishoftu - Ethiopia. Link: https://bit.ly/35hGNC1

44. ICMSF (1988) HACCP in Microbiological Safety and Quality. Internationa Commission on Microbiological Specifications for Foods. Oxford. Blackwell. Link: https://bit.ly/2SqeY7U

45. NACMCF (1993) Generic HACCP for raw beef. National Advisory Committee on Microbiological Criteria for Foods. US Department of Agriculture. Food Microbiology 10: 449-488.

46. Mead G (1997) Application of HACCP Principles in the Meat 1ndustry: a United Kingdom Perspective. University of London. United Kingdom. Link: https://bit.ly/3gqggrm

47. Rhea $F$ (2009) HACCP in meat and meat product manufacture in meat products. Leather head publishing, Leatherhead Surrey.

48. Silva J, Leite D, Fernandes M, Mena C, Gibbs PA, et al. (2011) Campylobacte spp. as a Foodborne Pathogen. A Review. Front Microbiol 2: 200. Link: https://bit.ly/3pOtlz7

Citation: Mustefa WS (2021) Review on application of hazard analysis critical control point in ethiopian slaughtering plant. Int J Vet Sci Res 7(1): 040-056. DOI: https://dx.doi.org/10.17352/ijvsr.000079 
49. Ansari-Lari M, Soodbakhsh S, Lakzadeh L (2010) Knowledge, Attitudes and Practices of Workers on Food Hygienic Practices in Meat Processing Plants in Fars, Iran. Food Control 21: 260-263. Link: https://bit.ly/35fBaV1

50. Havelaar AH, Kirk MD, Torgerson PR, Gibb HJ, Hald T, et al. (2015) World Health Organization Global Estimates and Regional Comparisons of the Burden of Foodborne Disease in 2010. Link: https://bit.ly/3glFngg

51. Ministry of Agriculture (2000) Meat hygiene requirements for export abattoirs. Addis Ababa, Ethiopia

52. Kebede T, Afera B, Taddele H, Bsrat A (2014) Assessment of bacteriological quality of sold meat in the butcher shops of adigrat, tigray, Ethiopia. Applied Journal of Hygiene 3: 38-44. Link: https://bit.ly/3zrv3dS

53. Stellato G, La Storia A, De Filippis F, Borriello G, Villani F, et al. (2016) Overlap of spoilage-associated microbiota between meat and the meat processing environment in smallscale and large-scale retail distributions. Applied and Environmental Microbiology 82: 4045-4054. Link: https://bit.ly/3xg17jd

54. Holck A, Axelsson L, McLeod A, Rode TM, Heir E (2017) Health and safety considerations of fermented sausages. Journal of Food Quality. Article ID 9753894.Link: https://bit.ly/3pObh8f

55. Lues JF, Van Tonder I (2017) The Occurrence of Indicator Bacteria on Hands and Aprons of Food Handlers in the Delicatessen Sections of Retail Group. Food Control 18: 326-332. Link: https://bit.ly/3wqjthl

56. Eshetie T, Hussien K, Teshome T, Mekonnen A (2018) Meat Production Consumption and Marketing Tradeoffs and Potentials in Ethiopia and Its Effect on GDP Growth: a review. Link: https://bit.ly/3iKnARz

57. Abayneh E, Nolkes D, Asrade B (2014) Review on Common Food borne Pathogens in Ethiopia. Afr $\mathrm{J}$ Microbiol 8: 4027-4040. Link: https://bit.ly/3cCHA4o

58. Lawrie RA, Ledward DA (2006) Lawrie's meat science. 7th ed. Woodhead Publishing Ltd., Cambridge, UK. Link: https://bit.ly/3ilYr9F

59. Sigge GO, Neethling NE, Suman SP, Hoffman LC, Hante MC (2017) Exogenous and Endogenous Factors Influencing Color of Fresh Meat from Ungulates. Meat and Muscle Biology.

60. Kirchofer KS, Calkins CB, Gwartney BL (2002) Fiber- type composition of muscles of the beef chuck and round. J Anim Sci 80: 2872-2878. Link: https://bit.ly/3zoZzp2

61. Avery A (2004) Red Meat and Poultry Production and Consumption in Ethiopia and Distribution in Addis Ababa. Borlaug-Ruan World Food Prize Intern International Livestock Research. Link: https://bit.ly/3vlKa5w

62. David H (2008) Feeding to Produce Export Quality Ethiopian Beef Requirements and Recommendations. Ethiopia Sanitary and Phytosanitary Standards and Livestock and Meat Marketing Program (SPS-LMM). Texas Agricultural Experiment Station (TAES)/Texas A\&M University System.

63. Gregory NG (2010) How climatic changes could affect meat quality. Food Research International 43: 1866-1873. Link: https://bit.ly/3vnogi6

64. Hall JT, Latschar C, Mackintosh D (1944) Characteristics of dark-cutting beef Survey and preliminary investigations. Kansas: Kansas Agric Exp Stat Tech Bull 58

65. Ashwani K, Etsay K, Enquebaher K (2009) Evaluation of quality of beef produced and sold in parts of Tigray Region of Ethiopia. Trop Anim Health Prod 42: 445-449. Link: https://bit.ly/2U3Sgmp

66. Mummed YY, Webb EC (2015) Carcass quality audit - A strategy to improve beef sector in Ethiopia10. African Journal of Agricultural Research 10: 27312737. Link: https://bit.ly/3zicLvE

67. Thomson G, Tambi E, Hargreaves S, Leyland T, Catley A, et al. (2004) International trade in livestock and livestock products: the need for a commodity- based approach. Vet Rec 155: 429-433. Link: https://bit.ly/3cCUAai

68. Antonia G (2013) Animal welfare in Ethiopia: handling of cattle during transport and operations at Kera Abattoir, Addis Abeba. First cycle, G2E. Uppsala: SLU, Dept. of Animal Nutrition and Management. Link: https://bit.ly/3vs3Zs4

69. FAO (2013) FAO. Retrieved from Manual for the slaughter of small ruminants in developing countries. Link: https://bit.ly/3zmGZxD

70. Helps C, Hindellb P, Hillmana T, Fishera AH, Anila A, et al. (2002) Contamination of beef carcasses by spinal cord tissue during splitting. Food Control 13: 417 423. Link: https://bit.ly/3xjUV9T

71. RMAA (Red Meat Abattoir Association) (2011) Animal handling practica guidelines for abattoirs. South Africa.

72. Brasesco F, Asgedom D, Sommacal V (2019) Strategic analysis and intervention plan for live animals and red meat in the Agro-Commodities Procurement Zone of the pilot Integrated Agro-Industrial Park in Centra Eastern Oromia, Ethiopia. Addis Ababa. FAO. Addis Ababa, Ethiopia.

73. Abegaz M (2004) UNIDO Food Safety and Technology Projects Coordinato and Consultant, Gap Analysis Report, Recommendations \& Proposals on Food Control System in Ethiopia, UNIDO's Regional Programme on Harmonization of Food Control System in East-Africa, December 2003, Addis Ababa, paper presented in Uganda, Kampala, for regional workshop on "Regional Harmonization of Food safety and Quality System in East Africa" 25-27 Feb. 2004

74. Yalemtsehay M (2010) Food safety and codex activities in Ethiopia Performance of the National Codex Committee of Ethiopia.

75. EASE (1987) Ethiopian Authority for Standardization Establishmen Proclamation No. 328/1987, Negarit Gazeta, 46th year No. 20.

76. NCC (2010) National Conference on Food Safety and CODEX activities in Ethiopia.

77. Tesfa T (2010) Food Quality Regulation in Ethiopia. Addis Ababa, Ethiopia.

78. Meat inspection proclamation (1970) Meat inspection proclamation No.274/1970, Negarit Gazeta, $29^{\text {th }}$ year, No.15.

79. FDRE Ministry of Industry (2015) Agro-Industry Strategy Meat Industry SubSector Strategic Plan (2015- 2025). Addis Ababa, Ethiopia.

80. NEPAD-CAADP (New Partnership for Africa's Development- Comprehensive Africa Agriculture Development Programme) (2005) Ethiopia: Investmen project profile 'Live Animal and Meat Export'- Preliminary options outline.

81. FAO/WHO (1998) Guidance on regulatory assessment of the HACCP. Report of a joint FAO/WHO consultation on the role of government agency in assessing HACCP. Geneva. Link: https://bit.ly/2TqnrrQ

82. Jabbar MA, Grace D (2012) Regulations for safety of animal source foods in selected Sub-Saharan African countries: Current status and their implications. The Safe Food, Fair Food Project International Livestock Research Institute Nairobi, Kenya. Link: https://bit.ly/3vmnUZk

83. Codex (1989) Principles for the establishment and application of microbiological criteria for foods. CAC Procedural Manual $7^{\text {th }}$ Edn, Codex Alimentarius Commission, FAO, Rome.

84. FAO (2003) Committee on Agriculture, Biosecurity in Food and Agriculture.

85. Ashwani K, Etsay K, Enquebaher K (2009) Evaluation of quality of bee produced and sold in parts of Tigray Region of Ethiopia. Trop Anim Health Prod 42: 445-449. Link: https://bit.ly/2U3Sgmp

86. FAO (1998) Food Quality and Safety Systems - A Training Manual on Food Hygiene and the Hazard Analysis and Critical Control Point (HACCP) System. FAO, Rome. Link: https://bit.ly/35i1KwG

Citation: Mustefa WS (2021) Review on application of hazard analysis critical control point in ethiopian slaughtering plant. Int J Vet Sci Res 7(1): 040-056. DOI: https://dx.doi.org/10.17352/ijvsr.000079 
87. FAO (2004) Good practice for the meat industry. Foundation inernationale Carrefour, Rome Italy. Link: https://bit.ly/3cCIPR6
88. FAO (2008) Enhancing participation in codex activities: Trainer's Notes. FAO/ WHO Joint Publications. Link: https://bit.ly/3wIRP4Z

89. Ministry of Health. Food safety. Addis Ababa, Ethiopia.
Discover a bigger Impact and Visibility of your article publication with

Peertechz Publications
Highlights

* Signatory publisher of ORCID

* Signatory Publisher of DORA (San Francisco Declaration on Research Assessment)

* Articles archived in worlds' renowned service providers such as Portico, CNKI, AGRIS, TDNet, Base (Bielefeld University Library), CrossRef, Scilit, J-Gate etc.

* Journals indexed in ICMJE, SHERPA/ROMEO, Google Scholar etc.

* OAI-PMH (Open Archives Initiative Protocol for Metadata Harvesting)

* Dedicated Editorial Board for every journal

- Accurate and rapid peer-review process

* Increased citations of published articles through promotions

* Reduced timeline for article publication

Submit your articles and experience a new surge in publication services (https://www.peertechz.com/submission).

Peertechz journals wishes everlasting success in your every endeavours.

Copyright: @ 2021 Mustefa WS. This is an open-access article distributed under the terms of the Creative Commons Attribution License, which permits unrestricted use distribution, and reproduction in any medium, provided the original author and source are credited. 